\title{
EFEKTIVITAS MODEL PEMBELAJARAN MEANINGFUL INTRUCTIONAL DESIGN (MID) TERHADAP HASIL BELAJAR MATEMATIKA SISWA KELAS VIII MTSN MANYAK PAYED Syahfitri \\ Alumni Jurusan/Prodi Pendidikan Matematika IAIN Langsa \\ Email: syahfitri@gmail.com
}

\begin{abstract}
ABSTRAK
Tujuan penelitian ini untuk mengetahui apakah model pembelajaran Meaningful Intructional Design (MID) efektif terhadap hasil belajar matematika siswa kelas VIII MTsN Manyak Payed. pendekatan kuantitatif. Penelitian ini menggunakan rancangan penelitian desain randomized control group pretest-posttest dengan menggunakan dua kelompok penelitian. Kelompok penelitian eksperimen dengan menggunakan model pembelajaran MID dan penelitian kontrol tanpa menggunakan model pembelajaran MID. Populasi dalam penelitian ini adalah seluruh siswa kelas VIII MTsN Manyak Payed yang terdiri dari 5 (lima) kelas bejumlah 146 orang siswa. Pengambilan sampel pada penelitian ini dengan menggunakan teknik undian yaitu dengan membuat gulungan kertas yang berisi semua populasi dari semua kelas VIII yang terdiri dari 5 kelas, kemudian diambil dua gulungan kertas, gulungan kertas yang pertama sebagai kelas eksperimen yaitu kelas VIII A dengan jumlah siswa sebanyak 30 orang siswa dan gulungan kertas kedua sebagai kelas kontrol yaitu kelas VIII C dengan jumlah siswa sebanyak 30 orang siswa. Instrumen yang digunakan berupa tes berbentuk uraian terstruktur terdiri dari 5 butir soal yang telah divalidasi oleh siswa kelas IX B. Data yang terkumpul kemudian dianalisis dengan menggunakan uji-t. Berdasarkan hasil analisis data diperoleh $t_{\text {hitung }}=2,38$ dan $t_{\text {tabel }}=1,701$ pada taraf signifikan $\propto=0,05$, sehingga dapat diperoleh $t_{\text {hitung }}>t_{\text {tabel }}$ yaitu 2,38 $>1,701$ dan dinyatakan $H_{0}$ ditolak dan $H_{a}$ diterima. Dengan demikian dapat disimpulkan bahwa terdapat efektivitas dari model pembelajaran meaningful intrutional design (MID) terhadap hasil belajar matematika siswa VIII MTs Negeri Manyak Payed.
\end{abstract}

\section{Kata Kunci: Model Pembelajaran Meaningful Intructional Design (MID), Hasil Belajar Matematika.}

\section{PENDAHULUAN}

Pendidikan merupakan pondasi yang kokoh guna menyusun sendi-sendi kehidupan yang lainnya. Jika kualitas pendidikannya tinggi maka akan memberi output Sumber Daya Manusia (SDM) yang tinggi pula sehingga dengan Sumber Daya Manusia (SDM) yang tinggi itu pembangunan di segala sektor dapat dibangun berdasarkan otak yang cemerlang. Kualitas kehidupan suatu bangsa ditentukan oleh pendidikan, oleh karena itu pembaharuan pendidikan harus selalu dilakukan untuk meningkatkan kualitas pendidikan suatu bangsa.

Pendidikan diselenggarakan sebagai suatu usaha sadar dan terencana dalam upaya meningkatkan kualitas sumber daya manusia (SDM). Menurut Buchori dalam Trianto" "bahwa pendidikan yang baik adalah pendidikan yang tidak hanya mempersiapkan siswa untuk suatu

\footnotetext{
${ }^{1}$ Trianto. Model-Model Pembelajaran Inovatif Berorientasi Konstrutivistik. (Jakarta : prestasi pustaka. 2007),
} hlm 54 
profesi atau jabatan, tetapi untuk menyelesaikan masalah-masalah yang dihadapi dalam kehidupan sehari-hari". Maka dari itu pendidikan tidak luput pada proses belajar yang dilakukan dalam kehidupan siswa. Siswa belajar melalui interaksi untuk mendapatkan pengetahuan berupa kecakapan dan perubahan tingkah laku.

Pada dasarnya belajar merupakan proses perubahan perilaku dan pola pikir yang dialami oleh seseorang, misalnya dari sesuatu hlm yang tidak bisa menjadi bisa, dari tidak tahu menjadi tahu. Menurut Winantaputra ${ }^{2}$ "belajar adalah proses yang dilakukan oleh manusia untuk mendapatkan aneka ragam kemampuan, keterampilan dan sikap”. Rangkaian proses ini dalam bentuk formal (sekolah) dan non formal (masyarakat).

Belajar secara formal dapat membawa perubahan, berupa kecakapan baru melalui suatu usaha yang dilakukan disekolah. Melalui belajar seseorang dapat memahami sesuatu konsep yang baru. Pernyataan tersebut didukung oleh Dahar" "menyatakan bahwa belajar adalah suatu proses usaha yang dilakukan seseorang untuk memperoleh suatu perubahan tingkah laku yang baru secara keseluruhan, sebagai hasil pengalamannya sendiri dalam interaksi dengan lingkungan".

Pembelajaran matematika yang diterapkan di sekolah merupakan dasar yang sangat penting dalam keikutsertaannya dalam mencerdaskan kehidupan bangsa sekaligus dapat meningkatkan kualitas pendidikan di Indonesia. Banyaknya permasalahan dalam pendidikan matematika merupakan salah satu alasan untuk mereformasi pendidikan matematika di sekolah. Permasalahan - permasalahan tersebut salah satunya adalah rendahnya mutu pendidikan Indonesia.

Rendahnya mutu pendidikan ini dapat dilihat, antara lain, dari rendahnya rata-rata nilai Ujian Nasional (UN) untuk semua bidang studi yang di-UN-kan, baik di tingkat nasional maupun daerah. Tetapi selain permasalahan - permasalahan yang muncul dari pelajaran matematika, matematika pun memiliki keistimewaan, salah satunya dengan muncul seorang matematikawan cilik yang berhasil mengungkapkan misteri kematian Michael Jackson menggunakan rumus rumus matematika.

Matematika merupakan salah satu mata pelajaran yang diajarkan pada jenjang pendidikan dasar dan menengah. Pelajaran matematika bertujuan untuk mempersiapkan siswa agar sanggup menghadapi perubahan keadaan dan memiliki ketrampilan serta cakap menyikapinya. Selain itu dengan permendiknas no. 22 tahun 2006 kelompok mata pelajaran ilmu pengetahuan dan teknologi pada SMP/MTs/SMPLB dimaksudkan untuk memperoleh kompetensi dasar ilmu pengetahuan dan teknologi serta membudayakan berpikir ilmiah secara kritis, kreatif dan mandiri. ${ }^{4}$

Kenyataan yang terjadi di lapangan, guru cenderung bersifat monoton dan hampir tanpa variasi kreatif dalam pembelajaran. Siswa beranggapan bahwa matematika adalah pelajaran yang sulit, tidak mampu menjawab, takut disuruh guru ke depan, dan sebagainya. Pembelajaran

\footnotetext{
${ }^{2}$ Winantaputra, Udin. S. dkk. Teori Belajar dan Pembelajaran.(Jakarta: Universitas Terbuka. 2009), hlm 15.

${ }^{3}$ Dahar, R.W. Teori-Teori Belajar dan Pembelajaran. (Jakarta: Erlangga. 2011),hlm.12.

${ }^{4}$ Lembaga penelitian dan pengabdian kepada masyarakat (LPPM) Universitas Mercu Buana Yogyakarta. Jurnal AgriSains Vol. 5 No. 2, September 2014, hlm 169
} 
matematika di dalam kelas harus dikelola sebaik mungkin, karena apabila guru masih bersifat monoton di dalam kelas akan membuat siswa menjadi pasif. Aktivitas mereka hanya mendengarkan, mencatat, dan mengerjakan apa yang disuruh oleh guru, sehingga pembelajaran yang dilakukan oleh guru menjadi pembelajaran yang tidak bermakna. Aktivitas yang dilakukan siswa seperti inilah yang menghambat kemajuan pendidikan di Indonesia.

Dari uraian-uraian di atas guru harus lebih peka terhadap kebutuhan siswa, sehingga siswa tidak merasa malas, bosan dalam menerima pelajaran. Guru dapat menggunakan metodemetode baru yang akan membuat siswa aktif dan berfikir kreatif dalam belajar sehingga prestasi siswa dapat meningkat.

Berdasarkan penelitian Ruspiani, hasil belajar matematika siswa selama ini masih belum menggembirakan khususnya dalam aspek koneksi matematis. ${ }^{5}$ Ruspiani menjelaskan bahwa hlm ini disebabkan antara lain karena model pembelajaran matematika kurang mendorong siswa berinteraksi dengan sesama siswa dalam belajar, dan kurang mendorong siswa dalam melihat keterkaitan antara topik-topik dalam matematika. ${ }^{6}$

Kemampuan mengaitkan konsep-konsep matematika baik antar konsep dalam matematika itu sendiri maupun mengaitkan konsep matematika dengan konsep dalam bidang lainnya disebut dengan kemampuan koneksi matematis. ${ }^{7}$ Permana dan Sumarmo dalam Russefendi ${ }^{8}$ menyimpulkan bahwa pemahaman siswa tentang koneksi antar konsep atau ideide matematika akan memfasilitasi kemampuan siswa untuk memformulasi dan memverifikasi konjektur secara induktif dan deduktif.

Koneksi matematis akan membuat matematika dimengerti dan bermakna, karena membantu siswa mempelajari konsep yang baru dan membantu siswa dalam melihat bahwa matematika merupakan sesuatu yang masuk akal. Selain itu, koneksi matematis juga membantu siswa mengingat suatu konsep dan menggunakannya secara tepat dalam situasi pemecahan masalah, serta memungkinkan siswa untuk menerapkan matematika dalam mata pelajaran lain atau dalam kehidupan sehari-hari.

Ketika siswa dapat melihat keterkaitan antara seluruh komponen yang berbeda dalam matematika, pandangan mereka akan berkembang menjadi matematika sebagai suatu keseluruhan yang terintegrasi. Siswa belajar konsep baru dengan membangun pemahaman matematika sebelumnya, sehingga mereka akan menjadi sadar akan hubungan antara berbagai topik matematika.

Gagne dan Berliner dalam Trianto ${ }^{9}$ mengungkapkan jika dalam kegiatan pembelajaran, isi pembelajaran dikaitkan dengan sesuatu yang telah dikenal atau yang telah dipelajari sebelumnya, maka siswa akan lebih termotivasi dalam belajarnya. Selain itu, pengetahuan siswa

${ }^{5}$ Ruspiandi, Nurul. Penerapan Model Pembelajaran Kooperatif MID dengan Menggunakan Alat Peraga Untuk Meningkatkan Hasil Belajar Siswa di Kelas VIII SMP N 1 Argamakmur. (Bengkulu, 2000), hlm 36. Diakses pada 01 Februari 2016 pukul 15:15 wib.

${ }^{6} \mathrm{Ibid}, \mathrm{hlm} 40$

${ }^{7} \mathrm{Ibid}, \mathrm{hlm} 64$

${ }^{8}$ E.T, Ruseffendi. Dasar-Dasar Penelitian Pendidikan dan Bidang Non Eksakta Lainnya. Bandung: Tarsito, hlm

67.

${ }^{9}$ Trianto. 2010. Mendesain Model Pembelajaran Inofatif Progressif, Jakarta : Prenada Media Group, hlm 39. 
tentang matematika dan kemampuan siswa dalam menggunakan berbagai representasi matematis, serta koneksi yang mereka buat dengan disiplin ilmu lainnya, pada akhirnya akan memberikan siswa kekuatan matematika yang lebih besar. Oleh karena itu siswa harus dibimbing dan didorong untuk mengembangkan kemampuan koneksi matematis.

Untuk menguasai pelajaran matematika disekolah secara baik diperlukan model pembelajaran yang memperhatikan keragaman individu siswa. Hlm ini sesuai dengan prinsip Kurikulum Tingkat Satuan Pendidikan, yakni siswa harus

mendapatkan pelayanan pendidikan yang bermutu, serta memperoleh kesempatan untuk mengekspresikan dirinya secara bebas, dinamis, dan menyenangkan.

Berdasarkan hasil wawancara dengan guru matematika yang mengajar di kelas VIII MTs Negeri Manyak Payed menyatakan bahwa, meskipun materi pelajaran sudah disampaikan oleh guru namun banyak siswa yang masih kesulitan dalam menyelesaikan soal-soal matematika, apalagi ketika guru memberikan soal yang berkaitan terhadap materi yang sebelumnya, terutama pada materi lingkaran, sehingga siswa beranggapan bahwa materi lingkaran adalah materi yang sulit difahami, sehingga berdampak pada hasil belajar siswa yang kurang maksimal, terbukti dari data yang diperoleh oleh guru, nilai rata-rata siswa yakni 59,8 masih rendah sekali dari kriteria ketuntasan minimal (KKM) senilai 75.

Hlm ini menunjukkan bahwa siswa masih belum fokus disaat mereka melakukan kegiatan belajarnya. Peneliti juga melakukan wawancara dengan 32 orang siswa. Tentang alasan mereka tidak berkonsentrasi dalam pembelajaran, diantaranya adalah $37.5 \%$ atau 12 siswa mengaku kurang menyukai pelajaran, $31.25 \%$ atau 10 siswa mengantuk dan tidak memperhatikan guru menjelaskan, $6.25 \%$ atau 2 siswa terlalu sibuk dengan urusan mereka sendiri dan sisanya $25 \%$ atau 8 siswa yang fokus belajar. Hlm ini sungguh sangat mengganggu kegiatan pembelajaran, yang juga akan berpengaruh pada hasil belajar yang diperoleh nantinya.

Berdasarkan penjelasan di atas, salah satu model pembelajaran yang dapat diterapkan untuk meningkatkan kemampuan koneksi matematis siswa adalah model pembelajaran Cooperative-Meaningful Instructional Design (C-MID). Meaningful learning merupakan strategi dasar dari pembelajaran konstruktivistik.

Ausubel dalam supriono ${ }^{10}$ menjelaskan bahwa meaningful learning (belajar bermakna) merupakan suatu proses mengaitkan informasi baru pada konsep-konsep relevan yang terdapat dalam struktur kognitif seseorang. Proses belajarnya mengutamakan kebermaknaan, agar peserta didik mudah mengingat kembali materi-materi yang telah disampaikan oleh guru ataupun materi yang baru disampaikan.

Instruction (pengajaran) dalam hlm ini tidak hanya merujuk kepada konteks pembelajaran formal di ruang kelas yang tujuan utamanya pemerolehan keterampilan dan konsep tertentu, tetapi juga memperhatikan sikap dan emosi siswa. Design (rancangan) ialah proses analisis dan sintesis yang dimulai dengan suatu masalah dan diakhiri dengan

${ }^{10}$ Suprijono, Agus. 2011. Coperatif Learning, Teori dan aplikasi PAIKEM. Yogyakarta: pustaka Pelajar, hlm 112. 
rencana solusi operasional. Jadi model pembelajaran C-MID adalah pembelajaran yang mengutamakan efektivitas dan kebermaknaan belajar dengan cara membuat kerangka kerja aktivitas secara konseptual kognitif konstruktivistik.

Berdasarkan uraian di atas, dilakukan penelitian dengan judul "Efektivitas Model Pembelajaran Meaningful Intructional Design (MID) terhadap Hasil Belajar Matematika Siswa Kelas VIII MTsN Manyak Payed."

\section{KAJIAN TEORI}

\section{Model Pembelajaran Meaningful Instructional Design (MID)}

Ausubel menyatakan: "Belajar bermakna merupakan suatu proses dikaitkannya informasi baru pada konsep-konsep relevan yang terdapat dalam struktur kognitif seseorang". " Untuk membuat matematika menjadi bermakna dan bermanfaat bagi siswa, maka diperlukan sebuah landasan untuk membangun kembali semua aspek pembelajaran matematika, seperti: bahanbahan kurikulum, lingkungan atau tempat pembelajaran, tanggung jawab guru, dan metode untuk menilai pemahaman matematika. Pernyataan tersebut di ungkapkan oleh Posamentier dan Stepelman.

Selain dari hlm yang disebutkan di atas, upaya untuk membuat pembelajaran matematika menjadi bermakna adalah dengan memberikan kesempatan kepada masing-masing siswa untuk membuat bahan ajar dan mengonstruksi soal-soal sendiri, sehingga diharapkan mereka dapat belajar dari pengalaman dan dapat mengingat materi yang dipelajari dalam waktu yang sangat panjang.

Sesuatu dikatakan bermakna jika berada pada tempatnya. Hamalik menyatakan : ${ }^{12}$

Keseluruhan memberikan makna kepada bagian-bagian, bagian-bagian terjadi dalam suatu keseluruhan. Bagian-bagian itu hanya bermakna dalam rangka keseluruhan tersebut. Ini berarti keseluruhan yang memberikan makna terhadap suatu bagian, misalnya sebuah ban mobil hanya bermakna jika menjadi bagian dari mobil, yakni sebagai roda, sebuah papan tulis hanya bermakna jika berada dalam kelas, sebatang kayu hanya bermakna sebagai sebagai tiang bila menjadi salah satu bagian pada sebuah rumah.

Dengan kata lain pembelajaran matematika akan bermakna jika menjadi bagian dari kebutuhan siswa. Sehingga, jika pembelajaran matematika telah bermakna di mata siswa, maka diharapkan siswa dapat mengembangkan kemampuan komunikasi matematikanya.

Madjid dalam Astety ${ }^{13}$ mengemukakan bahwa model pembelajaran bermakna adalah pola (pattern) atau kerangka kerja (frame work) yang dibangun secara konseptual, memiliki karakteristik khusus, dan berpijak pada psikologi kognitif-konstruktif untuk mewujudkan

${ }^{11}$ Astuty Yensy. B, Nurul. 2012. Penerapan Model Pembelajaran Kooperatif MID dengan Menggunakan Alat Peraga Untuk Meningkatkan Hasil Belajar Siswa di Kelas VIII SMP N 1 Argamakmur. (Bengkulu, 2012) (online). Diakses 1 Februari 2016, hlm 19

${ }_{13}^{12} \mathrm{Ibid}$. hlm 45.

${ }^{13}$ Astuty Yensy. B, Nurul. 2012. Penerapan Model Pembelajaran Kooperatif MID dengan Menggunakan Alat Peraga Untuk Meningkatkan Hasil Belajar Siswa di Kelas VIII SMP N 1 Argamakmur. (Bengkulu, 2012) (online). Diakses 1 Februari 2016, hlm 25. 
pembelajaran yang bermakna dan efektif. Untuk selanjutnya model pembelajaran bermakna yang dikembangkan oleh Madjid ${ }^{14}$ tersebut dinamakan The Meaningfull Instructional Design Model (The MID-Model) yang memiliki beberapa fase, hasil dari adaptasi dengan Model 4Mat system pada pembelajaran bahasa. Desain The MID-Model ini terdiri atas beberapa komponen, yaitu: (1) tujuan, (2) materi / bahan ajar, (3) sumber belajar, dan (4) prosedur, yaitu: "(a) lead individu (b) Reconstruction, dan (c) Production" serta (5) Evaluasi.

\section{Hasil Belajar}

Menurut Nana Sudjana hasil belajar adalah suatu akibat dari proses belajar dengan menggunakan alat pengukuran, yaitu tes yang disusun secara terencana, baik tes tertulis, tes lisan maupun ntes perbuatan. Kemudian S.Nasution menyatakan bahwa hasil belajar adalah suatu perubahan pada individu yang belajar, tidak hanya mengenai pengetahuan, tetapi juga membentuk kecakapan dan penghayatan dari dalam diri pribadi individu yang belajar. Sedangkan menurut Hamalik hasil belajar menunjukkan kepada prestasi belajar, sedangkan prestasi belajar itu merupakan indikator adanya derajat perubahan tingkah laku siswa ${ }^{15}$.

Berdasarkan beberapa pendapat para ahli diatas mengenai hasil belajar, maka dapat disimpulkan bahwa hasil belajar merupakan hasil yang diperoleh siswa setelah terjadinya proses pembelajaran yang ditunjukkan dengan nilai tes yang diberikan oleh guru setiap selesai memberikan materi pelajaran pada satu pokok bahasan.

\section{METODE PENELITIAN}

Dalam penelitian ini peneliti menggunakan pendekatan penelitian kuantitatif dengan metode eksperimen. Penelitian ini menggunakan rancangan penelitian Desain Randomized Control Group Pretest-Posttest dengan menggunakan pembagian dua kelompok penelitian yaitu kelompok penelitian eksperimen dengan menggunakan model pembelajaran meaningful instructional design dan kelompok penelitian kontrol tanpa menggunakan model pembelajaran meaningful instructional design (model konvensional).

\section{HASIL PENELITIAN}

Tabel Rata-rata Nilai Pre-test dan Post-test Hasil Belajar Matematika Kelas Eksperimen dan Kelas Kontrol

\begin{tabular}{|c|c|c|c|c|}
\hline \multirow{2}{*}{ Aspek } & \multicolumn{4}{|c|}{ Kelompok } \\
\cline { 2 - 5 } & \multicolumn{2}{|c|}{ Eksperimen } & \multicolumn{2}{c|}{ Kontrol } \\
\hline Rata-rata & Pretest & Postest & Pretest & Postest \\
\hline Nilai minimum & 38,3 & 82,9 & 47,5 & 73,7 \\
\hline Nilai maksimum & 64 & 60 & 28 & 56 \\
\hline $\begin{array}{c}\text { Jumlah siswa yang } \\
\text { tuntas }\end{array}$ & - & 94 & 62 & 90 \\
\hline
\end{tabular}

${ }^{14}$ Ibid, hlm. 26.

${ }^{15}$ Oemar Hamalik, Proses Belajar Mengajar, (Jakarta: Bumi Aksara, 2001) hlm.159 
Tabel Data Pre-test Hasil Belajar Matematika Siswa

\begin{tabular}{|c|c|c|}
\hline Aspek & Kelas Eksperimen & Kelas Kontrol \\
\hline$x_{\min }$ & 30 & 28 \\
\hline$x_{\operatorname{maks}}$ & 64 & 62 \\
\hline $\bar{x}$ & 47,7 & 47,4 \\
\hline$S$ & 10,02 & 8,49 \\
\hline
\end{tabular}

Tabel Hasil Uji Normalitas Pre-test

\begin{tabular}{|c|c|c|c|}
\hline Kelas & $\boldsymbol{\chi}^{\mathbf{2}}{ }_{\text {hitung }}$ & $\boldsymbol{\chi}_{\text {tabel }}$ & Kesimpulan \\
\hline Eksperimen & 6,08 & 11,07 & Normal \\
\hline Kontrol & 1,84 & 11,07 & Normal \\
\hline
\end{tabular}

Tabel Hasil Uji Homogenitas Pre-test

\begin{tabular}{|c|c|c|c|c|c|c|}
\hline Kelas & $\overline{\boldsymbol{x}}$ & $\boldsymbol{S}^{\mathbf{2}}$ & $\boldsymbol{S}$ & $F_{\text {hitung }}$ & $F_{\text {tabel }}$ & Kesimpulan \\
\hline Eksperimen & 48,3 & 100,51 & 10,02 & 1,39 & 1,68 & Homogen \\
\hline
\end{tabular}

Tabel Hasil Uji Kesamaan Dua Rata-rata Pretest

\begin{tabular}{|c|c|c|c|c|c|c|}
\hline \multirow{2}{*}{ Kelas } & $\overline{\boldsymbol{x}}$ & $\boldsymbol{S}^{\mathbf{2}}$ & $\boldsymbol{S}$ & \multicolumn{2}{|c|}{ Nilai t } & \multirow{2}{*}{ Kesimpulan } \\
\cline { 5 - 6 } & & $\boldsymbol{t}_{\text {hitung }}$ & $\boldsymbol{t}_{\text {tabel }}$ & $H_{0}$ diterima \\
Eksperimen & 48,3 & 100,51 & 10,02 & 0,36 & 1,59 & $\begin{array}{c}\text { dan } \\
H_{a} \text { ditolak }\end{array}$ \\
\hline
\end{tabular}

Tabel Data Post-test Hasil belajar matematika siswa Matematika Siswa

\begin{tabular}{|c|c|c|}
\hline Aspek & Kelas Eksperimen & Kelas Kontrol \\
\hline $\boldsymbol{x}_{\boldsymbol{m i n}}$ & 64 & 58 \\
\hline $\boldsymbol{x}_{\boldsymbol{m a k s}}$ & 97 & 92 \\
\hline$\overline{\boldsymbol{x}}$ & 83,25 & 77,35 \\
\hline $\boldsymbol{S}$ & 10,76 & 10,33 \\
\hline
\end{tabular}

Tabel Hasil Uji Normalitas Post-test

\begin{tabular}{|c|c|c|c|}
\hline Kelas & $\boldsymbol{\chi}^{\mathbf{2}}{ }_{\text {hitung }}$ & $\boldsymbol{\chi}^{\mathbf{2}}{ }_{\text {tabel }}$ & Kesimpulan \\
\hline Eksperimen & 8,08 & 11,07 & Normal \\
\hline Kontrol & 2,23 & 11,07 & Normal \\
\hline
\end{tabular}

Tabel Hasil Uji Homogenitas Post-test

\begin{tabular}{|c|c|c|c|c|c|c|}
\hline Kelas & $\overline{\boldsymbol{x}}$ & $\boldsymbol{S}^{\mathbf{2}}$ & $\boldsymbol{S}$ & $F_{\text {hitung }}$ & $F_{\text {tabel }}$ & Kesimpulan \\
\hline Eksperimen & 82,9 & 80,94 & 8,99 & 1,03 & 1,68 & Homogen \\
\hline
\end{tabular}




\section{KESIMPULAN}

Berdasarkan hasil penelitian dan pembahasan pada bab IV sebelumnya, dapat disimpulkan bahwa: Hasil uji hipotesis data post-test diperoleh $\quad t_{\text {hitung }}=2,38$ dengan $d k=30-1$ maka diperoleh $t_{\text {tabel }}=1,701$ sehingga $t_{\text {hitung }}>t_{\text {tabel }}$ maka dapat ditarik kesimpulan bahwa $H_{a}$ diterima dan $H_{o}$ ditolak pada taraf signifikan $\alpha=0,05$. Dengan demikian dapat disimpulkan bahwa terdapat efektivitas dari model pembelajaran meaningful intrutional design (MID) terhadap hasil belajar matematika siswa VIII MTs Negeri Manyak Payed.

\section{DAFTAR PUSTAKA}

Abdussakir.2009.Pembelajaran Geometri dan Teori Van Hele.(online).Tersedia : http://abdussakir.wordpres.com/2003/01/25/pembelajaran geometri teori van hele. Diakses pada 24 Maret

Anggun Diana Sari. Friska. 2012. Pemanfaatan Program Cabri 3D dalam Pembelajaran Matematika pada Materi Bangun Ruang Sisi Lengkung Kelas IX SMP dalam Upaya Meningkatkan Hasil Belajar Siswa, (Jurnal Pendidikan Matematika Fmipa UNY)

Astuty Yensy. B, Nurul. 2012. Penerapan Model Pembelajaran Kooperatif MID dengan Menggunakan Alat Peraga Untuk Meningkatkan Hasil Belajar Siswa di Kelas VIII SMP N 1 Argamakmur. (Bengkulu, 2012) (online). Diakses 1 Februari 2016

Aunurrahman. 2010. Belajar dan Pembelajaran. Bandung : Penerbit Alfabeta

Dimyati dan Mudjiono. 2006. Belajar dan pembelajaran. Jakarta : Rineka Cipta

E.T, Ruseffendi, 2005. Dasar-Dasar Penelitian Pendidikan dan Bidang Non Eksakta Lainnya. Bandung: Tarsito

Istarani. 2012. 58 Model Pembelajaran Inovatif. Medan: Media Persada

Iswanto, Dedi. http://matematikadedi.wordpress.com/2012/08/07/definisi-geometri, diakses 22 jan

Mardoto, HDI Indonesia (online,http//infopendidikankita.blogspot.com) diakses pada 11 Maret

Md. Kurniati, Ni. 2010. Pengaruh Metode Picture And Picture Terhadap Hasil Belajar Siswa Kelas IV SD Semester Genap Di Gugus I Kecamatan Buleleng, Singaraja: Jurusan Pendidikan Guru Sekolah Dasar, FKIP Universitas Pendidikan Ganesha

Riduwan. 2010. Belajar Mudah Penelitian untuk Guru Karyawan dan Peneliti Muda. Bandung: Alfabeta

Rofi'ah, Zainur. 2010. Pengaruh Pendekatan Picture And Picture Dengan Mengoptimalkan Barang Bekas Sebagai Media Pembelajaran Terhadap Prestasi Belajar Matematika Pada Keliling dan Luas Segi Empat Ditinjau Dari Motivasi Belajar Siswa. Skripsi, Surakarta: SI PENDIDIKAN MATEMATIKA UMS

Rusman. 2001. Model-model Pembelajaran Mengembangkan Profesionalisme Guru. Jakarta: Raja Grafindo Persada 
Setiady, Purnomo \& Husaini Usman. 2006. Pengantar Statistika. Jakarta: Bumi Aksara Sudjana, Nana. 2004. Penilaian Hasil Proses Belajar Mengajar. Bandng: Remaja Rosdakarya Suherman, Erman. 2003. Strategi Pembelajaran Kontemporer. Bandung: JICA

Slameto. 2003. Belajar dan Faktor-Faktor yang Mempengaruhinya. Jakarta: Rineka Cipta Sugiono. 2010. Metode Penelitian Kuantitatif dan Kualitatif dan $r \& d$. Bandung : Alfabeta

Suprijono, Agus. 2011. Coperatif Learning, Teori dan aplikasi PAIKEM. Yogyakarta: pustaka Pelajar

Trianto. 2010. Mendesain Model Pembelajaran Inofatif Progressif, Jakarta : Prenada Media Group

Winkel. 1996. Psikologi Pendidikan dan Evaluasi Pendidikan. Jakarta: Bima Aksara 